\title{
Should South Africa Criminalise Ukuthwala Leading to Forced Marriages and Child Marriages?
}

\author{
L Mwambene* and RH Mqidlana**
}

\section{P.E.R}

Pioneer in peer-reviewed, open access online law publications

\section{Authors}

Lea Mwambene

Roberta Hlalisa Mgidlana

\section{Affiliation}

University of the Western Cape South Africa

\section{Email}

Imwambene@uwc.ac.za robertamgidlana@gmail.com

Date Submission

20 January 2021

Date Revised

6 September 2021

Date Accepted

6 September 2021

Date published

30 September 2021

Editor Mr M Laubscher

How to cite this article

Mwambene L and Mgidlana RH "Should South Africa Criminalise Ukuthwala Leading to Forced

Marriages and Child Marriages?" PER / PELJ 2021(24) - DOI

http://dx.doi.org/10.17159/17273781/2021/v24i0a9423

\section{Copyright}

DOI http://dx.doi.org/10.17159/17273781/2021/v24i0a9423

\begin{abstract}
In 2014 the South African Law Reform Commission (SALRC) released a Discussion Paper on the practice of ukuthwala. The Discussion paper was revised and released again in 2015 to include public consultations and the proposed Prohibition of Forced Marriages and Child Marriages Bill (Prohibition Bill). The Prohibition Bill introduces an expanded crime of forced marriages and child marriages, including because of ukuthwala. In view of the SALRC's proposed Prohibition Bill, this paper investigates whether South Africa should criminalise ukuthwala or not. The paper also examines the advantages and disadvantages of criminalising breaches of ukuthwala in the protection of women and girls affected by the practice by drawing upon the field research findings from the community where the $S$ v Jezile 20152 SACR 452 (WCC) case originated. Among other findings, the field research show that the practice of ukuthwala is deeply rooted in the communities where it is still prevalent to the extent that the approach taken by the Prohibition Bill, expecting the victims to report their own parents or family members to law enforcement agents, might force the practice to go underground. Ultimately, we suspect that this might make it more difficult to protect women and children's rights violations associated with ukuthwala. We therefore recommend that to effectively address the malpractices surrounding ukuthwala, the process of law reform look at the elements of ukuthwala, the procedure that is followed, appreciate the cultural significance of the practice, as well as understand the merits and demerits of the customary delictual claims that are already used by communities where processes of the practice have been breached. In this way, communities will be more receptive to any government's efforts that are aimed at addressing forced and child marriages linked to ukuthwala. In addition, we submit that unless government prioritises awareness campaigns into the communities that are going to be affected by the proposed law reform, such law, will again be what Himonga calls "paper law".
\end{abstract}

\section{Keywords}

Ukuthwala; child marriage; forced marriage; Prohibition Bill; South Africa; Children's Act; Domestic Violence Act; South African Law Reform Commission; girls; criminalise. 


\section{Introduction}

In 2009, the Gender Directorate called upon the South African Law Reform Commission (SALRC) to investigate the impact of the practice of ukuthwala on the girl child, and to explore whether there are appropriate and adequate laws on the practice which uphold the human rights of the girl child. ${ }^{1}$ In 2014 , the SALRC released a Discussion Paper on the practice of ukuthwala. ${ }^{2}$ The latter paper was revised and released again in 2015 to include public consultations and the proposed Prohibition of Forced Marriages and Child Marriages Bill (Prohibition Bill). ${ }^{3}$ The Prohibition Bill introduces an expanded crime of forced marriages and child marriages, including as a result of ukuthwala.

In view of the SALRC's proposed Prohibition Bill, this paper will investigate whether South Africa should criminalise ukuthwala or not. The paper also examines the advantages and disadvantages of criminalising breaches of ukuthwala by drawing upon the field research findings from the community where the $S$ v Jezile 20152 SACR 452 (WCC) case originated. ${ }^{4}$ The paper is therefore divided as follows: Part one is this introductory section. Part two provides an overview of the Prohibition Bill. This is then followed by a critical analysis of the Prohibition Bill in part three. The fourth part provides a brief overview on theoretical perspectives on criminalising harmful cultural practices generally. The fifth part is a discussion of the advantages and disadvantages of criminalising forced marriages and child marriages because of ukuthwala. Finally, in the sixth part, we conclude that unless government prioritises awareness campaigns into the communities that are going to be affected by the proposed law reform, such law, will again be what Himonga calls "paper law". ${ }^{5}$

\section{Overview of the Prohibition Bill}

The basic premise of the Prohibition Bill is to make forced marriages and child marriages an offence; thus, protecting both women and children subjected to ukuthwala leading to these marriages. The law seeks to

Lea Mwambene. Dip Nursing (UNIMA) LLB (Hons) (UNIMA) LLM LLD (UWC). Professor, University of the Western Cape, South Africa. Email: Imwambene@uwc.ac.za. ORCID: https://orcid.org/0000-0002-4822-5394.

* Roberta Hlalisa Mgidlana. LLB (UWC) LLM (Leiden University) LLM (UWC). Email: robertamgidlana@gmail.com. ORCID: https://orcid.org/0000-0003-0474-9759.

SALRC Revised Discussion Paper 1381.

SALRC Discussion Paper 132.

SALRC Revised Discussion Paper 13857.

This research was conducted in Engcobo and surrounding areas in September 2015 and April 2016. Engcobo is an area north of Mthatha which falls within the Chris Hani District Municipality of the Eastern Cape Province. Yes Media 2017 https://municipalities.co.za/overview/1021/engcobo-local-municipality.

5 Himonga "African Customary Law and Children's Rights" 85. 
prevent forced marriage and child marriage by making certain actions punishable, and by calling for the prosecution of persons who commit such actions. ${ }^{6}$ The Prohibition Bill therefore introduces an extended crime of forced marriage, prohibits child marriage and criminalises forced marriages. ${ }^{7}$ Section 1 of the Prohibition Bill proposes the following definitions for both forced marriages and child marriage:

A child marriage is defined as a marriage relationship or cognate union where one or both of the parties are children, and the marriage was without the consent and free will of one or both of the parties. ${ }^{8}$

A forced marriage refers to a marriage relationship or cognate union entered into without the consent and free will of one of the parties and includes those marriage relationships or cognate unions purporting to be contracted in pursuit of such practices such as ukuthwala, shobediso, tjhobediso, kutlhaka, thlakisa, tahisa, kutaha and tshabisa, ukweba umakoti or any similar practice. ${ }^{9}$

The above definition seems to comply with international standards. For example, the Economic and Social Affairs Division for the Advancement of Women (DAW/DESA) ${ }^{10}$ proposes that a law must provide clear definitions of forced marriage and child marriage; "and any definition of forced marriage must be broad enough to encompass the whole array of practices related to this issue". ${ }^{11}$ More importantly, the above definition captures the element of "the lack of free and full consent" as crucial in defining what a forced marriage or child marriage is under the Prohibition Bill. Indeed, "free and full consent" of both parties has long been established under international law as an important requirement for a valid marriage. ${ }^{12}$ This provision, therefore, may be significant for the protection of persons over the age of 18 in addressing forced marriages. However, the fulfilment of this requirement is

6 Section 3(3) of the Prohibition of Forced Marriages and Child Marriages Bill, 2015 (the Prohibition Bill).

Preamble of the Prohibition Bill.

Section 1 of the Prohibition Bill.

Section 1 of the Prohibition Bill. Emphasis added.

UN Supplement to the DAW/DESA Handbook.

UN Supplement to the DAW/DESA Handbook 23.

Article 16(2) of the Universal Declaration of Human Rights (1948) (UDHR);art 1(1) of the Convention on Consent to Marriage, Minimum Age for Marriage and Registration of Marriages (1962) (the Marriage Convention); art 23(3) of the International Covenant on Civil and Political Rights (1966) (the ICCPR); art 16(1)(b) of the Convention on the Elimination of All Forms of Discrimination Against Women (1979) (CEDAW); art 6(a) of the Protocol the African Charter on Human and People's Rights on the Rights of Women in Africa (2003) (the Maputo Protocol); art 8(2)(b) of the Southern African Development Community Gender Protocol (2008) (the SADC Gender Protocol); and art 8(2) of the African Charter on the Rights and Welfare of the Child (1990) (the African Youth Charter). 
suspect to the protection of persons below 18 from child marriage since they have no legal capacity to give consent. ${ }^{13}$

The Prohibition Bill further seeks to ensure investigation, prosecution and punishment of perpetrators. Accordingly, section 2 of the Prohibition Bill provides that:

The objects of the Act are to ensure that marriages are entered into freely and without any form of coercion; to prohibit child marriages and forced marriages and to ensure the prosecution of persons who commit offences provided for in the Act and for appropriate penalties. ${ }^{14}$

Importantly, the Prohibition Bill makes it an offence to force a person into marriage in the following manner:

3(1) A person commits the offence of forced marriage if he or she-

(a) uses violence, threats or any other form of coercion for the purposes of causing another person to enter into a marriage, and

(b) believes or ought to believe that the conduct may cause the other person to enter into the marriage without free and full consent.

(2) In relation to any person who by reason of mental capacity or any such reason lacks capacity to consent to a marriage, the offence under subsection (1) is capable of being committed by any conduct carried out for the purpose of causing that person to enter into a marriage (whether or not the conduct amounts to violence, threats or any other form of coercion).

(3) Any person who-
(a) attempts;
(b) conspires with any other person; or
(c) aids, abets, induces, incites, instigates, instructs, commands, counsels or procures another person,

to commit an offence in terms of this Act, is guilty of an offence and may be liable on conviction to the punishment to which a person convicted of actually committing that offence would be liable. ${ }^{15}$

Drawing from the recommendation made by DAW/DESA, the creation of a broad offence on forced marriage as outlined in the above provision allows the full range of such marriages to be punishable under the law. ${ }^{16}$ Moreover, the coercion of a person to enter into marriage against her will is prohibited

\footnotetext{
13 Askari 1998 ILSA J Int'I \& Comp L 136.

14 Section 2 of the Prohibition Bill.

15 Section 3 of the Prohibition Bill.

16 UN Supplement to the DAW/DESA Handbook 24.
} 
in section 3(1) of the Prohibition Bill. In addition, several parties are heavily involved in the process of ukuthwala that may lead to forced marriages and the betrothal and marriage of children. ${ }^{17}$ Therefore, the Prohibition Bill in section 3(3) explicitly addresses the criminal responsibility of those involved in the arrangement of a forced marriage. Persons, including parents, guardians or family members who convene a child marriage are liable for prosecution.

Furthermore, the Prohibition Bill makes child marriage an offence in section 4 as follows:

A person commits a child marriage offence if he or she enters into a marriage or cognate union with a child, unless he or she complies with the provisions of the RCMA, Marriage Act and Children's Act. ${ }^{18}$

Besides criminalising forced marriages and child marriage, section 5 of the Prohibition Bill provides that the accused may be found guilty of the offences of abduction, kidnapping, assault, trafficking or any other criminal act in the event that the evidence on the charge of forced marriage or child marriage does not prove the offence. ${ }^{19}$ This provision, arguably, provides additional protection in ensuring that persons accused of forced marriages or child marriage can still be held liable for criminal acts surrounding these marriages. More importantly, section 6 of the Prohibition Bill provides a list of punishments for persons found guilty of the offences referred to in sections 3, 4 and 5 . These include: imprisonment for a period in line with the punishment prescribed for the offences of assault, abduction, kidnapping, rape and human trafficking or a fine or both, imprisonment or fine. ${ }^{20}$

Finally, section 7 of the Prohibition Bill provides for the issuance of forced marriage protection orders. ${ }^{21}$ Forced marriage protection orders are defined as:

An order issued by the court to prohibit a person from committing or aiding to commit the offence of forced marriage or child marriage, or if such purported marriage has taken place, an order issued by the court compelling the respondent(s) to terminate such marriage and to allow the victim to return to his or her place of residence before such purported marriage took place. ${ }^{22}$

See for example Rex $v$ Swartbooi 1916 EDL 170.

Section 4 of the Prohibition Bill.

Section 5 of the Prohibition Bill.

Section 6 of the Prohibition Bill.

Section 7 of the Prohibition Bill.

Section 1 of the Prohibition Bill. 
It is also important to note that the Prohibition Bill provides that forced marriage protection order may be issued against more than one person. ${ }^{23}$ In terms of section 7(b)(ii)-(iii), the terms of the order may, in particular:

...relate to respondents who are, or may become involved in other respects as well as, or instead of, respondents who force or attempt to force, or may force or attempt to force, a person into marriage; and other persons who are, or may become, involved in other respects as well as respondents of any kind. $^{24}$

This provision is precisely important in addressing child marriages or forced marriages that may be because of ukuthwala. As generally observed, the procedure followed during ukuthwala leading to the conclusion of the customary marriage involves more than one person. ${ }^{25}$

\section{Critical analysis of the Prohibition Bill}

From the foregoing brief overview, the Prohibition Bill is a welcome step to eradicate forced marriages and child marriage generally, and the malpractices around ukuthwala in particular. However, it is noted that the Prohibition Bill is by no means perfect. Below we elaborate on this point by highlighting some issues.

The provisions of the Prohibition Bill outlined above, are more geared towards the perpetrator, and not on the principle that victims of such marriages are entitled to prompt redress for the harm that they suffer. ${ }^{26}$ This can be illustrated by the fact that the Prohibition Bill provides no details about the protection, support and assistance for survivors and information relating to service providers. ${ }^{27}$ In agreement with the recommendations by DAW/DESA, it is important that legislative measures should not only aim to criminalise, but also identify appropriate rights and remedies for victims of forced marriage and child marriage. ${ }^{28}$ Arguably, clear details about the protection and assistance for these victims would, empower victims to report knowing that they are protected by the law.

In addition, the Prohibition Bill does not provide a procedure where the victim may report such forced marriage or child marriage. Put it differently, the Prohibition Bill is silent regarding who to report an incidence of child marriage to, such as police officers, a Child Welfare Organisation or Child

\footnotetext{
23 Section 7(b)(ii)-(iii) of the Prohibition Bill.

24 Section 7(b)(ii)-(iii) of the Prohibition Bill.

25 See generally discussions by Mwambene and Sloth-Nielsen 2011 AHRLJ 1-22; Koyana and Bekker 2007 De Jure 139-144; Karimakwenda 2013 Acta Juridica 339356; Rice 2014 Journal of Southern African Studies 381-399.

26 See generally ss 4, 5 and 6 of the Prohibition Bill

27 UN Supplement to the DAW/DESA Handbook 12.

28 UN Supplement to the DAW/DESA Handbook 28-29.
} 
Line. Arguably, the absence of provisions regarding who to report an incident of child marriage in the Prohibition Bill could be problematic. It creates a situation where victims may be sent from one office to the other, with implications of deterring victims from coming forward to report such cases. The Prohibition Bill does also not provide a list of persons who may file a complaint or report an incidence of child marriage. It is general knowledge that persons who may have reasonable information to believe that a child marriage is likely to take place/took place in the community may include school teachers, doctors, neighbours, parent or guardian of the child or non-governmental organisations. Arguably, listing persons to report cases of force marriage and child marriage, may directly impose responsibilities on everyone listed, thereby offering more protection to possible victims in the communities.

Furthermore, borrowing from DAW/DESA recommendation, the Prohibition Bill does not mandate the appointment of specialised protection officers who have undergone dedicated training in relation to forced marriage and child marriage, which would, arguably, create an individual safety plan for each survivor. ${ }^{29}$ The importance of appointing specialised and trained protection officers cannot be overemphasised. As correctly pointed, appointment of specialised protection officers ensures that:

The survivor has access to legal aid; maintaining a list of service providers to whom they can refer the survivor; preparing an incident report which is to be submitted to a magistrate; taking the survivor to a shelter, as well as to be medically examined and/or treated if it is so required. ${ }^{30}$

In addition, the shortcomings in the Prohibition Bill could also be well understood when compared to, for example, chapter 5 of the Prevention and Combating of Trafficking in Persons Act 7 of 2013 (Trafficking Act). ${ }^{31}$ The Trafficking Act entrenches a victim-centred approach and promotes better service delivery to respond to the needs of victims. ${ }^{32}$ It prioritises the welfare of victims during investigations and prosecutions by referring victims only to organisations accredited to receive adult victims of trafficking, which provide the following:

Access to and provision of adequate healthcare, counselling programmes and reintegration measures, and a plan to address the immediate and reasonable future needs of that victim. ${ }^{33}$

UN Supplement to the DAW/DESA Handbook 28.

UN Supplement to the DAW/DESA Handbook 28.

Sections 24, 25, 26 and 28 of the Prevention and Prohibition of Trafficking in Persons

Act 7 of 2013 (the Trafficking Act).

32 Section 3 of the Trafficking Act.

33 Sections 24, 25 and 28 of the Trafficking Act.
} 
Similarly, section 191(2)(f) of the Children's Act provides that "a child and youth care centre must offer a therapeutic programme designed for the reception and temporary safe care of trafficked children". ${ }^{34}$ As pointed out, it is unfortunate that the Prohibition Bill is silent of the abovementioned similar provisions.

Furthermore, the Prohibition Bill does not provide for guidance on protocols for various sectors in cases of suspected or actual forced marriage and child marriage. ${ }^{35}$ Again, if one is to compare to other legislation, for example, section 110 of the Children's Act, it provides obligations on various sectors for reporting of abused or neglected children or children in need of care and protection. ${ }^{36}$ As described by Hendriks, such a provision compels certain professional sectors to report any child abuse or neglect that is suspected on reasonable grounds to a designated child protection organisation, the provincial Department of Social Development or a police official. ${ }^{37}$ The Children's Act further stipulates that the Department of Social Development must assess and further manage the situation in the best interests of the child. ${ }^{38}$

Moreover, it should be noted that even though the Prohibition Bill stipulates that a person commits the offence of forced marriage if he or she uses violence, threats or any other form of coercion for the purpose of causing another person to enter into a marriage, ${ }^{39}$ it does not provide for the consequence of such a marriage. There is no provision indicating the voidability or annulment of such a marriage. To compare with a civil marriage, for example, a court may declare a civil marriage null and void if the formal and material requirements are not complied with. ${ }^{40}$ The grounds for voidability of a civil marriage, for example include, minority, material mistake, duress and undue influence. ${ }^{41}$

Additionally, the Prohibition Bill does not propose amendments to laws to prevent harmful practices related to forced marriage and child marriage. ${ }^{42}$ Such proposals could be on provisions in the Recognition of Customary Marriages Act (RCMA), Marriage Act, and the Children's Act, which allow

\footnotetext{
34 Section 191(2)(f) of the Children's Act 38 of 2005.

35 UN Supplement to the DAW/DESA Handbook 29.

36 Section 110 of the Children's Act 38 of 2005.

37 Hendriks 2014 SAMJ 551.

38 Hendriks 2014 SAMJ 551.

39 Section 3 of the Prohibition Bill.

$40 \quad$ Heaton and Kruger South African Family Law 33.

41 Heaton and Kruger South African Family Law 34-38. Similarly, putative marriages, where one or both parties enter into a civil marriage while being unaware that there is a defect which renders the marriage void, may also be set aside.

42 Supplement to the DAW/DESA Handbook for Legislation on Violence against Women (2011) 31.
} 
minors to get married if consent of guardians is obtained. Instead, the Prohibition Bill demands compliance with legislation such as the RCMA, Marriage Act and Children's Act, which, unfortunately, allow child marriage. This position, arguably, may create an opportunity for condoning ukuthwala that leads to a forced marriage or child marriage.

More importantly, and linking to the discussion to follow in section four of this paper, DAW/DESA provides that:

Legislation preventing harmful practices must seek to acknowledge that communities have an integral role to play in the abandonment of forced marriages and child marriages, and call for government support for community-based abandonment initiatives that are targeted at changing behaviour and attitudes, and the training of traditional leaders about modern policies protecting women and children. ${ }^{43}$

On the other hand, the Prohibition Bill is silent. The role of the government to support community initiatives is not mentioned. ${ }^{44}$

To add to the above, the Prohibition Bill neither provides for reporting procedures for complainants, arrests, nor does it designate officers to assist complainants. Arguably, a similar provision to section 2 of the Domestic Violence Act (DVA) would assist complainants when reporting. Section 2 of the DVA, which is titled, "duty to assist and inform complainant of rights", ${ }^{45}$ provides that:

\begin{abstract}
A South African Police Service member has an obligation to attend to a complainant who has reported domestic violence by (a) assisting or making arrangements for the complainant to find a suitable shelter and to obtain medical treatment, (b) providing information in the language of the complainant, and (c) explaining to the complainant his or her right to lodge a complaint.
\end{abstract}

Section 2 is buffered by section 3 of the DVA which allows for arrest without a warrant.

Furthermore, the verdicts and penalties found in the Prohibition Bill are already provided for in other legislations, including, the Criminal Law (Sexual Offences and Related Matters) Amendments Acts of 2007 and 2015, and the Trafficking Act. We therefore wonder if it is necessary to have a separate legislation or not. Moreover, the Prohibition Bill, just like other existing legislations, also fall short of providing for aspects of forced marriage inter alia, persuasion, control, pressure, threats and manipulation that many victims, particularly in ukuthwala, face over time, which are also

\footnotetext{
43 UN Supplement to the DAW/DESA Handbook 33.

44 Contrast this with provisions where a Minister is required to furnish his consent for child marriages.

$45 \quad$ Domestic Violence Act 116 of 1998.
} 
silent in the existing criminal offences. ${ }^{46}$ Moreover, Karimakwenda found that in terms of ukuthwala, there are certain factors that are used to determine whether the act of sexually violating a woman is criminal or a sanctioned form of coercion such as whether the man sexually assaulted the woman with the intention of making her his wife or not. ${ }^{47}$ As pointed out by Mwambene and Sloth-Nielsen, the issue, therefore, is how to address the objectionable forms of the practice of ukuthwala through criminalisation without losing the culturally-beneficial aspects of the practice. ${ }^{48}$

\section{Criminalising harmful cultural practices generally}

The concept of "harmful traditional practices", though not defined precisely, seem to include:

Practices that are likely to negatively affect the child's life, health, social welfare, dignity, physical or psychological development, such as circumcision and other genital mutilations, virginity testing, child betrothals and child marriages. ${ }^{49}$

Originated in the United Nations circles, resolutions were adopted by the General Assembly "calling on all States to abolish harmful customs, laws and practices by eliminating child marriages and the betrothal of young girls before the age of puberty, and establishing appropriate penalties where necessary". ${ }^{0}$ The concept started to gain more currency following the Convention on the Elimination of All Forms of Discrimination Against Women (1979) (CEDAW), and the founding of the CEDAW Committee. As Banda observes, several general recommendations made by the CEDAW Committee have identified culture, among others, as being an impediment to the enjoyment of women's rights. ${ }^{51}$

Harmful cultural practices are also condemned by feminists who believe that their support and continuation is closely tied to patriarchy and structures that support it. ${ }^{52}$ They generally argue that, for example, these patriarchal systems tend to exert control over women's sexuality and marriageability ${ }^{53}$ and reinforce inequality and discriminate against women and girl children. ${ }^{54}$

Proudman 2014 https://www.charlotteproudman.com/wp-content/uploads/2014/08/ crim-of-FM.Famlaw.pdf 3.

$47 \quad$ Karimakwenda 2013 AHRLJ 352.

$48 \quad$ Mwambene and Sloth-Nielsen 2011 AHRLJ 7.

$49 \quad$ Himonga "African Customary Law and Children's Rights" 84.

50 In 1958 and 1961, the UN Economic and Social Council invited the World Health Organisation to study customs subjecting girls to ritual operations, making female genital mutilation gain the most attention.

51 Banda Women, Law and Human Rights 249.

52 Diop, Stewart and Herr "Black African Feminist Theory to Examine FGM" 13.

53

Glover et al 2018 Journal of International Women's Studies 58-59.

54

Mubangizi 2012 Journal of International Women's Studies 34. 
Mubangizi, among others, also perceive harmful cultural practices as an effort to control women's sexuality, as well as their reproductive capacity. ${ }^{55}$ In addition, Universalist holds that each human being possesses inalienable rights regardless of religion, gender or age. ${ }^{56}$ This position was reinforced by the international community during the Vienna Programme of Action where it was agreed that "all human rights are universal, interdependent, interrelated and indivisible". ${ }^{57}$

Cultural relativists, on the other hand, argue that each culture has the liberty to practice what is native and relevant to that society without the imperialist imposition from another culture that holds a different set of beliefs and or norms. ${ }^{58}$ According to Nhlapo, not all challenges to traditional practices are illegitimate. He argues that Western scholars should be tolerant, respectful and prepared to interact better to understand cultures. ${ }^{59}$ Verkuyten, Kumar and Adelman argues that "tolerance forms a barrier against discrimination, hostility, conflict and is a critical condition for citizenship and democracy". ${ }^{60}$ They further observe that tolerance is about the balancing of reasons "to object to certain out-group beliefs and practices with reasons to nevertheless accept them". ${ }^{61}$

In order to counteract, some scholars have argued that "the demand for cultural preservation disproportionally hampers women's struggle for the full enjoyment of human rights". ${ }^{62}$ Asomah's contention is that "cultural preservation should be assessed solely on the basis of its usefulness, not on the grounds of preservation of cultural identity and traditions when, in fact, doing so would result in the erosion of the dignity, liberty and security of others". ${ }^{63}$ The implication is that cultural practices should not prevail over individual human rights. On the other hand, Nyamu-Musembi proposes that "instead of abolishing customs, we should examine local cultures attentively and see which aspects we can best use to achieve the aspirations of human rights". ${ }^{64}$ Similarly, Idang argues that although some cultural practices have negative elements which must be abandoned, the positive aspects of

55 Mubangizi 2015 Journal of International Women's Studies 159. See also Danial 2013 Prandium 3.

The concept of "human rights" refers us to a body of international law, consisting of the UDHR, the ICCPR, the International Covenant on Economic, Social and Cultural Rights (1966) (the ICESCR), and a host of special multilateral treaties sponsored by the United Nations. Reichert 2006 Journal of Comparative Social Welfare 24. Vienna Declaration and Programme of Action (1993) adopted by the World Conference on Human Rights on 25 June 1993, para 5.

58 Danial 2013 Prandium 2.

$59 \quad$ Nhlapo "African Customary Law Marriage" 15-16.

Verkuyten, Kumar and Adelman 2019 Social Issues and Policy Review 28.

Verkuyten, Kumar and Adelman 2019 Social Issues and Policy Review 28.

Asomah 2015 AHRLJ 133.

Asomah 2015 AHRLJ 134.

Nyami-Musembi "Are Local Norms and Practices Fences or Pathways?" 126. 
customs ought to be practiced and passed onto future generations. ${ }^{65} \mathrm{He}$ makes a compelling argument that culture is not stagnant but rather an adaptive system with values that play a significant role in giving society its uniqueness. So, just like other cultural relativists who differentiate between harmful and harmless cultural practices, proposes that only the negative and harmful traditional practices that dehumanise people should be discarded immediately. ${ }^{66}$

In reconciling universalism and cultural relativism, some authors have proposed guidelines to help identify and resolve conflicts between local cultural, religious and legal norms and universal principles of human rights. An-Na'im suggests an approach which prioritises "internal cultural discourse and cross-cultural dialogue". He opines "there may be room for changing a cultural position from within, through internal discourse about the fundamental values of the culture and the rationale for these values". ${ }^{67}$ However, in Durojaye's view, it is uncertain how this balance can be successfully be achieved particularly in an environment like Africa with deep-rooted patriarchal traditions where women's voices are still suppressed. ${ }^{68}$ The issue of whether prohibition through legislation alone is appropriate, Van Bueren argues that "to implement children's rights in one culture is not simply a matter of translation but attention has to be paid to the functions they perform in different traditions". 69 According to her, children's rights have a better prospect for implementation if they reflect local cultural beliefs. ${ }^{70}$ Mwambene and Kruuse also argue that a bottom-up approach would enable more effective responses to the specific challenges of a particular community. Hence, local needs and issues must be considered as the point of departure for action. ${ }^{71}$

Furthermore, Reichert suggests the following in addressing the conflict: "(i) examining the history of cultural practices, (ii) examining the power brokers who determine the cultural norm and (iii) analysing the cultural practice within a contemporary human rights standard". ${ }^{72}$ Applying the first guideline by Reichert, we see that ukuthwala is a long-standing practice which is carried out to open up marriage negotiations. As explained by the chief in the Jezile community, after the man has initiated the process by informing his parents that he wishes to marry, intlola (inspectors) visit the girl's family

Idang 2015 Phronimon 98.

Idang 2015 Phronimon 110.

An-Na'im "Towards a Cross-Cultural Approach to Defining International Standards of Human Rights" 4.

Durojaye 2016 IJDL 235.

Van Bueren "Children's Rights" 17.

Van Bueren "Children's Rights" 17.

Mwambene and Kruuse 2017 SAJHR 3.

Reichert 2006 Journal of Comparative Social Welfare 31. 
and observe the kind of people they are i.e. whether "the girl is brought up in a respectful home". Thereafter onozakuzaku (husband's family delegate) are sent to propose marriage. ${ }^{73}$ The implication is that the practice is not aimed at abducting girls randomly.

Regarding the second guideline, similar to other cultural practices, the decision-making process in ukuthwala is male dominated. Onozakuzaku and intlola constitute uncles, headmen and other male relatives. Arguably, women have limited influence regarding the ukuthwala process, and generally decision-making that shape the marriage that is eventually concluded. ${ }^{74}$

Applying the third guideline, Durojaye argues that "if a cultural practice seems to be manifestly inconsistent with human rights principles and standards, then it does not deserve to be retained". ${ }^{75}$ This is similar to arguments made by Kheswa and Hoho as well as Maluleke that ukuthwala raises human rights challenges and infringes the constitutional rights of women and girl children and therefore it should not prevail over these rights. ${ }^{76}$ However, based on the observations during the field research in Engcobo, focusing on the distortions surrounding the ukuthwala would be more effective in protecting other human rights. In this regard, the chief stated as follows:

\begin{abstract}
As a community that practices our custom, our tradition, we believe in our custom. This custom was practiced by our forefathers so therefore we cannot say that we are going to discontinue practising it. If there are things that are not done correctly, in this custom of ukuthwala, we are willing to change. We can practice the custom but in a different way as how our parents used to, but we are not going to stop practicing our customs. Our lives are based on our customs. ${ }^{77}$
\end{abstract}

The foregoing theoretical perspectives on criminalising harmful cultural practices, including ukuthwala, seem to suggest that culture is vilified as something from which women and girl children should be liberated. ${ }^{78}$

\title{
5 Should ukuthwala leading to forced and child marriages be criminalised?
}

In examining several competing divergent views on the criminalisation of ukuthwala, we draw upon the arguments outlined in the SALRC report, as well as the field research findings conducted in the community where the

Group interview with women, 2015.

Msuya Harmful Cultural and Traditional Practices 236.

Durojaye 2016 IJDL 236.

Kheswa and Hoho 2014 MJSS 2811. See also Maluleke 2012 PELJ 18.

Interview with chief and his delegate, 2015.

Vaezy Woman's Right to Culture. 
Jezile case originated. The field research ${ }^{79}$ was conducted in Engcobo in 2015 and 2016, an area north of Mthatha which falls within the Chris Hani District Municipality of the Eastern Cape Province. ${ }^{80}$ In particular, we focus on several questions: what does criminalisation mean to communities that practice ukuthwala? How will criminalisation ensure that the rights of the woman and the girl child are adequately protected? How do we then ensure that a woman or girl will come forward to lay a charge if there lays the possibility of prosecution of her family and community members who were complicit in the act?

However, before we commence this discussion, a brief overview of what happened in the Jezile case may be necessary. Briefly, this case concerned the abduction, rape and assault of a 14-year-old in the disguise of ukuthwala. The complainant launched a complaint at the Magistrates' Court alleging that the accused, Jezile, had violated her rights by abducting, raping and assaulting her. ${ }^{81}$ The events which unfolded are that he had travelled to the Eastern Cape in search of a wife preferably a 16-year-old virgin girl. The complainant who was then 14 years of age met the eye of Jezile and he proceeded to prepare lobolo negotiations, concluded in one day. Jezile travelled with the complainant, who was unwilling at the time, to Cape Town. This is where the rape and assault occurred. The magistrate found him guilty and sentenced him to 22 years of imprisonment. ${ }^{82}$

Jezile appealed his conviction and sentence in the Western Cape High Court. On appeal he argued that he was practising the custom of ukuthwala. ${ }^{83}$ The court found that the offences for which he was charged took place after a traditional ukuthwala would have occurred. As a result, he could not in any event have placed reliance on the practice of ukuthwala as a justification for his conduct. It was concluded that he had relied on the "aberrant" form of ukuthwala as being the living form of customary law to justify his conduct. ${ }^{84}$

79 Ethics consent was obtained from the Humanities and Social Research Ethics Committee of the University of the Western Cape (ethics ref no: HS/16/3/6, reg no: 12/1/21). I adhere to concepts of the research ethics and informed consent. All participants in this study were informed of the purpose of the study, their informed consent was obtained, and anonymity guaranteed. Yes Media 2017 https://municipalities.co.za/overview/1021/engcobo-localmunicipality.

$81 S$ v Jezile 20152 SA 62 (WCC) para 1.

$82 \quad S v$ Jezile 20152 SA 62 (WCC) para 2.

$83 \quad S$ v Jezile 20152 SA 62 (WCC) para 42.

$84 \quad S$ v Jezile 20152 SA 62 (WCC) para 90. 


\subsection{Arguments against criminalisation of ukuthwala}

Research on the criminalisation of forced marriages and child marriages outlines persuasive arguments against criminalisation. The most compelling argument in support of not criminalising ukuthwala was on the premise that the community felt excluded from processes of deciding in laws which mainly affect them, by the following words:

Maybe before these laws are endorsed, they need to come to the traditional leaders so that these laws could be discussed thoroughly. ${ }^{85}$

The participants concerned were upset because, according to them, human rights and "white man's" courts make ukuthwala and other practices illegal in the absence of the necessary consultation on the ground level. The way in which the government treated the situation made the community very defensive. Like other research, this research shows that the government, and the human rights discourses appeared as evidence of outside interference, which was directed towards disrupting local customary practices. ${ }^{86}$

In Imoh's view, any dialogue on harmful cultural practices in a community needs to start from the community's own starting point in order to contextualise the custom. ${ }^{87}$ This dialogue, it is suggested, should encourage the community to discuss educational, health and development issues and work towards reaching a consensus on the human rights of women and girl children and the responsibilities of other community members such as, for example, the clan, chief and church. ${ }^{88}$ An informed dialogue between men, women and children will thus achieve the best results.

Furthermore, Proudman has warned that a specific criminal offence of forced marriages and child marriage, if effectively enforced, might discourage victims, especially child victims, from coming forward and seeking assistance for the fear that their parents or extended family members might be prosecuted. ${ }^{89}$ Indeed, the study conducted in Engcobo revealed the danger of complainants being ostracised by their family and the community at large. During the consultations, one participant indicated that the complainant in the Jezile case was "the first one to bring them problems". This was reiterated during a family discussion that the

\footnotetext{
$85 \quad$ Group interview, 2015.

86 Diala J \& Diala A 2017 Journal of Comparative Law in Africa 92; Smit Violent ReEmergence of Abduction Marriage 111.

87 Imoh 2016 Int'l J Children's Rts 469-487.

88 Imoh 2016 Int'l J Children's Rts 469-487.

89 Proudman 2014 https://www.charlotteproudman.com/wp-content/uploads/2014/08/ crim-of-FM.Famlaw.pdf 2.
} 
complainant had brought "shame" to the family and that the family "sympathised with Jezile". 90

In addition, a criminal law does not guarantee a conviction. There is a presumption that a person is innocent until proven guilty. ${ }^{91}$ Moreover, an accused may raise the defence that he was exercising his constitutional rights to culture, or the defence that he was deceived as to the age of the girl by either the girl or a person in whose charge she was in. ${ }^{92} \mathrm{~A}$ review of the cases considering the age defence indicates that it is often raised where the accused has not taken any steps to ascertain her age beyond a visual observation..$^{93}$ Indeed, during the family discussions in Engcobo, there was huge doubts on the victim's age as presented in court because the victim looked older than 14 years. In addition, the community's doubt about her age was linked to the fact that she was at the time in grade seven at school, and generally children only start school at the age of 10 because of the poor infrastructure in the area. However, Grant and Benedet persuasively argue that:

In cases where the accused argues that he was misled about the complainant's age, are just typical examples of stereotypical reasoning that girls are 'old enough' based on appearance, dress, alcohol consumption, and prior sexual experience. ${ }^{94}$

Therefore, such a defence provides a loophole for offenders who should be held accountable for their actions. ${ }^{95}$

Further research suggests that the introduction of a new criminal offence could cause duplication with the criminal offences that already exist, for example, kidnapping, imprisonment, child abduction, assault and rape. As seen in $S v$ Jezile, and as analysed in the previous section, Proudman points out that "despite the current array of criminal offences, they do not provide for victims of forced marriage who experience emotional and psychological force". ${ }^{96}$ She suggests that criminalisation, therefore, may not send out a strong public message to perpetrators that forced marriage and child marriage are legally unacceptable. Although it is hoped that criminalisation

\footnotetext{
$90 \quad$ Interview with complainant's family.

91 Section 35(3)(h) of the Constitution of the Republic of South Africa, 1996 (the Constitution). Section 15(1) of the Constitution; s 56(2) of the Criminal Law (Sexual Offences and Related Matters) Amendment Act 32 of 2007.

93 S V Sheldon-Lakey 20162 SACR 632 (NWM), Mthimunye v S2017 JOL 39057 (GP); Mohale v S 20192 SACR 666 (GP).

94 Grant and Benedet 2019 Can Bar Rev 6.

95 Grant and Benedet 2018 Can Bar Rev 6. See also for example Mohale v S 20192 SACR 666 (GP).

96 Proudman 2014 https://www.charlotteproudman.com/wp-content/uploads/2014/ 08/crim-of-FM.Famlaw.pdf 2.
} 
of forced marriages and child marriage as a result of ukuthwala would deter families from breaking the law due to the fear of prosecution, the research in Engcobo showed that the contrary may be true. In fact, the participants suggested that they should all have been prosecuted because they participated in the proceedings of the complainant's ukuthwala. ${ }^{97}$

From the above, we see that whilst all the participants saw the malpractices surrounding ukuthwala as unacceptable and offensive to their culture, little support was expressed for criminalising it because the community maintained that the processes of ukuthwala are different from criminal acts. The evidence indicates that a community-led change is favoured to address the current malpractices surrounding ukuthwala.

\subsection{Arguments for the criminalisation of ukuthwala}

Research also shows compelling arguments for the criminalisation of forced marriage and child marriage. The obvious main argument is that of the Centre for Constitutional Rights that the distortions surrounding the practice of ukuthwala are an unjustifiable violation of fundamental human rights, particularly the rights of women and girl children. ${ }^{98}$ The distorted versions of ukuthwala indicate that women who are married young are more likely to be beaten, threatened or raped and believe that a husband might sometimes be justified in beating his wife. ${ }^{99}$ Viewed this way, ukuthwala is an appalling and indefensible practice that is recognised as a form of violence against women, and where a minor is involved, child marriage.

The SALRC report highlighted views of proponents who vouch for the development of a new statute which would criminalise distorted ukuthwala on the following reasons. First, they argue that the seriousness of problems associated with ukuthwala (such as abduction, rape, force, conduct of guardians) are of such a magnitude that a clear law is necessary. ${ }^{100}$ Here we saw that the community had mixed reactions. On the one hand, they do not support this view because they are of the opinion that criminalisation of ukuthwala would be a direct infringement of their right to practice their culture and more significantly, they are excluded from the process of deciding on laws which mainly affect them. They had the following to say:

We celebrate our custom, we get into trouble, we go to prison, we get life sentences, losing your life, your future, by practising our customs...[yet]

\footnotetext{
$97 \quad$ Interview with Jezile family

98 Ntlokwana Submissions to the SA Law Commission paras 12-17.

99 Karimakwenda 2013 AHRLJ 353.

100 SALRC Revised Discussion Paper 13829.
} 
government preaches that we should preserve our customs ... but that gets us into trouble ... these laws are conflicting and its confusing [us] .... ${ }^{101}$

On the other hand, they agree that the distorted versions of ukuthwala warrant legal interference and they are willing to co-operate with legal officials to regulate the malpractices surrounding ukuthwala. The research in Engcobo showed that participants are willing to change aspects of ukuthwala which are wrong, however they will not abandon their custom. Participants had the following to say:

As a community we believe in our custom of ukuthwala, this custom was practiced by our forefathers so therefore we cannot say that we are going to discontinue practising it. If there are things that are not done accordingly, in this custom of ukuthwala, we are willing to change. ${ }^{102}$

Moreover, they strongly believe that mediation between families is an essential process in African customary law and suggest this to be the best solution in addressing the distorted versions of ukuthwala. ${ }^{103}$ Commenting on the outcome of the Jezile case, they proposed as follows:

Maybe the courts could go an extra mile, to get the two families together, outside the court environment, sort of mediation between families. ${ }^{104}$

Secondly, during the thwala process, violence is used. ${ }^{105}$ Proponents for criminalisation thus argue that violence against an individual is a grave invasion of personal security. This view indeed aligns with the Constitution ${ }^{106}$ that guarantees the right to be free from all forms of violence from either public or private sources and not to be tortured in anyway. ${ }^{107}$ Furthermore, everyone has the right to make decisions concerning reproduction and to security in, and control over their body. ${ }^{108}$ Thus, criminal penalties would arguably be more effective, sending a strong message by society that domestic violence and forced marriage will not be tolerated. However, criminalising violence in the context of ukuthwala is not so easy. Karimakwenda's study showed that violence in ukuthwala and marriage is not just part of an insular and rural way of life; it is part of a culture that permits and rationalises rape and violence against women. ${ }^{109}$

101 Interview with Jezile's family, 2015.

102 Interview with chief and his delegate, 2015.

103 Jezile family discussions, 2016.

104 Interview with chief and his delegate

105 Karimakwenda 2013 AHRLJ 339.

106 Section 12 of the Constitution.

107 Section 12(a) of the Constitution.

108 Section 12(b) of the Constitution. See Rautenbach and Matthee $2010 \mathrm{~J}$ Legal Plur 136.

109 Karimakwenda 2013 Acta Juridica 356. 
Thirdly, proponents for criminalisation argue that ukuthwala deprives girl children of opportunities to educate and develop themselves. ${ }^{110}$ In terms of section 29 of the Constitution, everyone has the right to basic education. It has been reported that married girls' access to education is severely limited because of "restrictions placed on mobility by domestic burdens, childbearing and social norms that view marriage and schooling as incompatible". 111 Moreover, parents tend not to invest in education of daughters because the benefits of their investments will be lost when they leave the parental home. ${ }^{112}$ The community had this to say:

Families are different on how they look at education. Around this area, schools are far and children have to walk about $3 \mathrm{~km}$ to go to school. You worry about your child having to walk such a long distance at a tender age and that is why they end up beginning school late. Furthermore, there is a river that they have to cross on their way to school and on rainy days it is difficult for them to cross over. Also, marrying off girls does not depend on education. If the man brings cows then it is fine. Some girls get married and with agreement with their husband they go back to school to finish up. ${ }^{113}$

The authors acknowledge that government has international and constitutional obligations to preserve and protect people's rights to practice their culture freely and that legislation aimed at outlawing the cultural practice of ukuthwala might infringe upon that right. It should be noted that not all forms of ukuthwala constitute an offence for example where the woman is made aware of the proceedings and she provides her consent. ${ }^{114}$ In such instances, ukuthwala can serve important cultural purposes in South African communities who live their lives according to cultural norms. ${ }^{115}$ Admittedly, a criminal law will provide rules to make the process safer by introducing the requirement of consent of the woman in all processes of ukuthwala. ${ }^{116}$ Proudman also argues that in the longer term, criminalisation will challenge community understandings of forced marriage and child marriage, as there is currently a fundamental problem in how legitimate consent and force are understood across cultures ${ }^{117}$. According to Proudman, a criminal offence may be necessary to "encompass the wide spectrum of coercive behaviour that may be exerted over a long period of time rather than as a one-off violent attack". She further argues that this will

\footnotetext{
110 Maluleke 2012 PELJ 12.

111 Mudzuru v Ministry of Justice, Legal and Parliamentary Affairs 2015 ZWCC 12 (20 January 2016) 41.

112 Mudzuru v Ministry of Justice, Legal and Parliamentary Affairs 2015 ZWCC 12 (20 January 2016) 41.

113 Interview with chief and his delegate, 2015.

114 Mwambene and Sloth-Nielsen 2011 AHRLJ 6-7. See also Oosthuizen and Ngema 2010 Speculum Juris $87-88$.

115 Mwambene and Sloth-Nielsen 2011 AHRLJ 5.

116 Section 3(b) of the Prohibition Bill.

117 Proudman 2014 https://www.charlotteproudman.com/wp-content/uploads/2014/08/ crim-of-FM.Famlaw.pdf 3.
} 
also provide justice for victims who do not have access to existing criminal law remedies due to a prioritisation of physical and sexual violence. ${ }^{118}$

\title{
6 Conclusion
}

In conclusion, this paper has shown that criminalisation of ukuthwala is a subject with diverse opinions. This poses a challenge in the South African legal system, especially in the areas of criminal law and customary law. At the heart of these divergent views is the notion that ukuthwala is a form of violence against women, and in particular girl children. This notion is supported by Prof Nhlapo's view that the modern form of ukuthwala has been distorted. However, adherents of customary law and customary practices are adamant that they are practising their culture. They have gone as far as saying that the outcome of the Jezile case ${ }^{119}$ will not deter them from practising ukuthwala. ${ }^{120}$ In their words:

\begin{abstract}
Let me just say, she was not the first to be thwalaed and she was not the last one to be thwalaed. There are girls who have been thwalaed after this case and they are still in their marriages. She was the first one who gave us problems. If you ask "How do I feel about practising ukuthwala after this case?" My answer is that ukuthwala is still going to be practiced even after this case..$^{121}$
\end{abstract}

The SALRC finding that the South African legal framework does not adequately address forced marriage and child marriage is correct. However, a critical analysis of the Prohibition Bill has shown that without clear guidance on how to handle cases, a stand-alone Prohibition Bill remains unnecessary. This does not mean that the criminalisation of forced marriages and child marriage should fall through the cracks. In essence, this calls for an approach concentrating on criminalising the aspects of the practice which perpetuate violence against women and the girl-child or generally human rights violations.

To answer the question whether criminalisation will be effective and sustainable in protecting women and the girl-child against harmful practices such as ukuthwala, we have outlined the advantages and disadvantages of criminalising forced and child marriages because of ukuthwala. We submit

\footnotetext{
118 Proudman 2014 https://www.charlotteproudman.com/wp-content/uploads/2014/08/ crim-of-FM.Famlaw.pdf 4.

119 S v Jezile 20152 SA 62 (WCC).

120 Family discussion, April 2016.

121 Chief and his delegates, 2015. From the above it can be deduced that the community outrightly defied the ban of marriages of young girls by arguing that they are practising their custom. Some have said that the prospect of ukuthwala is to deter girls from becoming pregnant out of wedlock and having lasting marriages. Viewed this way, in our opinion, it cannot be said that ukuthwala plays a legitimising function for children.
} 
that for South Africa to effectively address malpractices surrounding ukuthwala, it should look at the elements of ukuthwala, the procedure that is followed as well as the customary delictual claims that are already there in the communities aimed at addressing the malpractices of the custom. In this way, the communities will be more receptive. Ultimately, unless government prioritises community involvement, awareness campaigns into the communities that are going to be affected by the proposed law reform, such law, will again be what Himonga calls "paper law". ${ }^{122}$ Otherwise, we foresee a difficulty whereby there will be reluctance by the victims to send their own parents or family to jail. Focus should then be maximised on the victim by ensuring that measures are put in place to encourage support for the victims to come forward. The practice of ukuthwala is deeply rooted in African culture to the extent that outlawing it will arguably only serve as "paper law".

\section{Bibliography}

\section{Literature}

An-Na'im "Towards a Cross-Cultural Approach to Defining International Standards of Human Rights"

An-Na'im A "Towards a Cross-Cultural Approach to Defining International Standards of Human Rights: The Meaning of Cruel, Inhuman, or Degrading Treatment or Punishment" in An-Na'im A (ed) Human Rights in CrossCultural Perspectives: A Quest for Consensus (University of Pennsylvania Press Philadelphia 1992) 1-16

Askari 1998 ILSA J Int'l \& Comp L

Askari $L$ "The Convention on the Rights of the Child: The Necessity of Adding a Provision to Ban Marriages" 1998 ILSA J Int'l \& Comp L 123-138

Asomah 2015 AHRLJ

Asomah J "Cultural Rights Versus Human Rights: A Critical Analysis of the Trokosi Practice in Ghana and the Role of Civil Society" 2015 AHRLJ 129149

Banda Women, Law and Human Rights

Banda F Women, Law and Human Rights: An African Perspective (Hart Oxford 2005)

122 Himonga "African Customary Law and Children's Rights" 85. 
Danial 2013 Prandium

Danial S "Cultural Relativism vs Universalism: Female Genital Mutilation, Pragmatic Remedies" 2013 Prandium: The Journal of Historical Studies 110

Diala and Diala 2017 Journal of Comparative Law in Africa

Diala $\mathrm{J}$ and Diala A "Child Marriage, Bridewealth and Legal Pluralism in Africa" 2017 Journal of Comparative Law in Africa 77-104

Diop, Stewart and Herr "Black African Feminist Theory to Examine FGM" Diop M, Stewart P and Herr K "A Black African Feminist Theory to Examine Female Genital Mutilation (FGM) Within African Immigrant Families in the United States" unpublished contribution delivered at the National Council on Family Relations Annual Theory Construction and Research Methodology Workshop (14-15 November 2017 Orlando, Florida)

Durojaye 2016 IJDL

Durojaye E "The Human Rights Implications of Virginity Testing in South Africa" 2016 IJDL 228-246

Glover et al 2018 Journal of International Women's Studies

Glover $\mathrm{J}$ et al "Persistence and Resistance of Harmful Traditional (HTPs) Perpetuated Against Girls in Africa and Asia" 2018 Journal of International Women's Studies 44-64

Grant and Benedet 2019 Can Bar Rev

Grant I and Benedet J "Confronting the Sexual Assault of Teenage Girls: The Mistake of Age Defence in Canadian Sexual Assault Law" 2019 Can Bar Rev 1-42

Heaton and Kruger South African Family Law

Heaton $\mathrm{J}$ and Kruger $\mathrm{H}$ South African Family Law $4^{\text {th }}$ ed (LexisNexis Durban 2015)

Hendriks 2014 SAMJ

Hendriks ML "Mandatory Reporting of Child Abuse in South Africa: Legislation Explored" 2014 SAMJ 550-552

Himonga "African Customary Law and Children's Rights" Himonga C "African Customary Law and Children's Rights: Intersections and Domains in a New Era" in Sloth-Nielsen $\mathrm{J}$ (ed) Children's Rights in Africa: A Legal Perspective (Ashgate Burlington 2008) 73-90

Idang 2015 Phronimon Idang G "African Cultures and Values" 2015 Phronimon 97-111 
Imoh 2016 Int'l J Children's Rts

Imoh A "Tackling the Physical Punishment of Children in Resource Poor Contexts" 2016 Int'l J Children's Rts 469-487

Karimakwenda 2013 Acta Juridica

Karimakwenda N "Today It Would Be Called Rape: A Historical and Contextual Examination of Forced Marriage and Violence in the Eastern Cape" 2013 Acta Juridica 339-356

Kheswa and Hoho 2014 MJSS

Kheswa J and Hoho V "Ukuthwala: The Sexual-Cultural Practice with Negative Effects on the Personality of Adolescent Females in Africa" 2014 MJSS 2808-2813

Koyana and Bekker 2007 De Jure

Koyana DS and Bekker JC "The Indomitable Ukuthwala Custom" 2007 De Jure 139-144

Maluleke 2012 PELJ

Maluleke MJ "Culture, Tradition, Custom, Law and Gender Equality" 2012 PELJ 1-22

Msuya Harmful Cultural and Traditional Practices

Msuya N Harmful Cultural and Traditional Practices: A Roadblock in the Implementation of the Convention on the Elimination of Discrimination against Women and the Maputo Protocol on Women's Rights in Tanzania (PhD-thesis University of KwaZulu-Natal 2017)

Mubangizi 2012 Journal of International Women's Studies

Mubangizi J "A South African Perspective on the Clash Between Culture and Human Rights, with Particular Reference to Gender-Related Cultural Practices and Traditions" 2012 Journal of International Women's Studies 33-48

Mubangizi 2015 Journal of International Women's Studies

Mubangizi J "An Assessment of the Constitutional, Legislative and Judicial Measures Against Harmful Cultural Practices that Violate Sexual and Reproductive Rights of Women in South Africa" 2015 Journal of International Women's Studies 158-173

Mwambene and Sloth-Nielsen 2011 AHRLJ

Mwambene $L$ and Sloth-Nielsen J "Benign Accommodation? Ukuthwala, 'Forced Marriage' and the South African Children's Act" 2011 AHRLJ 1-22 
Mwambene and Kruuse 2017 SAJHR

Mwambene $L$ and Kruuse $H$ "The Thin Edge of the Wedge: Ukuthwala, Alienation and Consent" 2017 SAJHR 1-21

Nhlapo "African Customary Law Marriage"

Nhlapo $T$ "The African Customary Law Marriage and the Rights Conundrum" A Reading for the Course: LLM (Human Rights and Democratisation in Africa) (15 May 2012 Faculty of Law University of Pretoria)

Ntlokwana Submissions to the SA Law Commission

Ntlokwana N Submissions to the SA Law Commission on Ukuthwala Custom (Centre for Constitutional Rights Cape Town 2009)

Nyami-Musembi "Are Local Norms and Practices Fences or Pathways?" Nyami-Musembi C "Are Local Norms and Practices Fences or Pathways? The Example of Women's Property Rights" in An-Na'im A (ed) Cultural Transformation and Human Rights in Africa (Zed Books London 2002) 126150

Oosthuizen and Ngema 2010 Speculum Juris Oosthuizen T and Ngema NM "Ukuthwala: Structured for Relevance" 2010 Speculum Juris 84-102

Rautenbach and Matthee $2010 \mathrm{~J}$ Legal Plur

Rautenbach $\mathrm{C}$ and Matthee $\mathrm{J}$ "Common Law Crimes and Indigenous Customs: Dealing with the Issues in South African Law" $2010 \mathrm{~J}$ Legal Plur 109-144

Reichert 2006 Journal of Comparative Social Welfare

Reichert E "Human Rights: An Examination of Universalism and Cultural Relativism" 2006 Journal of Comparative Social Welfare 23-36

Rice 2014 Journal of Southern African Studies

Rice K "Ukuthwala in Rural South Africa: Abduction Marriages as a Site of Negotiation About Gender, Rights and Generational Authority Among the Xhosa" 2014 Journal of Southern African Studies 381-339

Smit Violent Re-Emergence of Abduction Marriage Smit WJ The Violent Re-Emergence of Abduction Marriage in Modern South Africa: Ukuthwala as a Diagnostic Event for Changing Marriage Practices and the Power of Discourse (LLD-thesis Raboud University Nijmegan 2017) 
SALRC Discussion Paper 132

South African Law Reform Commission Discussion Paper 132, Project 138

- The Practice of Ukuthwala (SALRC Pretoria 2014)

SALRC Revised Discussion Paper 138

South African Law Reform Commission Revised Discussion Paper 138, Project 138 The Practice of Ukuthwala (SALRC Pretoria 2015)

UN Supplement to the DAW/DESA Handbook

United Nations Supplement to the DAW/DESA Handbook for Legislation on Violence Against Women: Harmful Practices Against Women (United Nations New York 2011)

Vaezy Woman's Right to Culture

Vaezy L A Woman's Right to Culture: Toward Gendered Cultural Rights (Quid Pro Books New Orleans 2015)

Van Bueren "Children's Rights"

Van Bueren G "Children's Rights: Balancing Traditional Values and Cultural Plurality" in Douglas G and Sebba L (eds) Children's Rights and Traditional Values (Ashgate Aldershot 1998) 15-30

Verkuyten, Kumar and Adelman 2019 Social Issues and Policy Review Verkuyten M, Kumar $\mathrm{Y}$ and Adelman L "Intergroup Toleration and Its Implications for Culturally Diverse Societies" 2019 Social Issues and Policy Review 5-35

\section{Case law}

\section{South Africa}

Mohale v S 20192 SACR 666 (GP)

Mthimunye v S 2017 JOL 39057 (GP)

Rex $v$ Swartbooi 1916 EDL 170

$S$ v Jezile 20152 SA 62 (WCC)

S v Sheldon-Lakey 20162 SACR 632 (NWM)

\section{Zimbabwe}

Mudzuru v Ministry of Justice, Legal and Parliamentary Affairs 2015 ZWCC 12 (20 January 2016) 


\section{Legislation}

Children's Act 38 of 2005

Constitution of the Republic of South Africa, 1996

Criminal Law (Sexual Offences and Related Matters) Amendment Act 32 of 2007

Criminal Law (Sexual Offences and Related Matters) Amendment Act 5 of 2015

Domestic Violence Act 116 of 1998

Marriage Act 25 of 1961

Prevention and Prohibition of Trafficking in Persons Act 7 of 2013

Recognition of Customary Marriages Act 120 of 1998

\section{Government publications}

Prohibition of Forced Marriages and Child Marriages Bill, 2015

International instruments

African Charter on the Rights and Welfare of the Child (1990)

Convention on Consent to Marriage, Minimum Age for Marriage and Registration of Marriages (1962)

Convention on the Elimination of All Forms of Discrimination Against Women (1979)

International Covenant on Economic, Social and Cultural Rights (1966)

International Covenant on Civil and Political Rights (1966)

Protocol the African Charter on Human and People's Rights on the Rights of Women in Africa (2003)

Southern African Development Community Gender Protocol (2008)

Universal Declaration of Human Rights (1948)

Vienna Declaration and Programme of Action (1993) 


\section{Internet sources}

Proudman $2014 \quad$ https://www.charlotteproudman.com/wp-content/ uploads/2014/08/crim-of-FM.Famlaw.pdf

Proudman C 2014 The Criminalisation of Forced Marriage https://www.charlotteproudman.com/wp-content/uploads/2014/08/crim-of-

FM.Famlaw.pdf accessed 24 May 2021

Yes Media 2017 https://municipalities.co.za/overview/1021/engcobo-localmunicipality

Yes Media 2017 Engcobo Local Municipality: Geography, History and Economy https://municipalities.co.za/overview/1021/engcobo-localmunicipality accessed 17 March 2017

\section{List of Abbreviations}

AHRLJ

Can Bar Rev

CEDAW

DAW/DESA

DVA

ICESCR

ICCPR

IJDL

ILSA J Int'I \& Comp L

Int'l J Children's Rts

J Legal Plur

MJSS

PELJ

RCMA

SAJHR

SALRC

SAMJ

UDHR

UN
African Human Rights Law Journal

Canadian Bar Review

Convention on the Elimination of All Forms of Discrimination Against Women

Economic and Social Affairs Division for the Advancement of Women

Domestic Violence Act 116 of 1998

International Covenant on Economic, Social and Cultural Rights

International Covenant on Civil and Political Rights

International Journal of Discrimination and the Law

ILSA Journal of International and Comparative Law

International Journal of Children's Rights

Journal of Legal Pluralism and Unofficial

Law

Mediterranean Journal of Social Sciences

Potchefstroom Electronic Law Journal

Recognition of Customary Marriages Act 120 of 1998

South African Journal on Human Rights

South African Law Reform Commission

South African Medical Journal

Universal Declaration of Human Rights

United Nations 